\title{
An Overview of Teacher Education and the Teaching Profession in Saudi Arabia: Private vs. Public Sector
}

\author{
Wesal Maash \\ Graduate School of Education, University of Exeter, Exeter, United Kingdom \\ King Saud University, Riyadh, Saudi Arabia
}

\begin{abstract}
The premise of progress of countries depends largely on the success of their education systems. Many educators attribute the success of education to teachers, as they see teachers as the fundamental element in the educational process. The focus on teachers highlights the significance of their education, training and preparation. The aim of this paper is to provide an overview of how initial teacher education is currently structured in Saudi Arabia. It also aims to provide background on the context of the teaching profession in Saudi Arabia with a detailed description of the situation of teachers who work in private schools. The significance of this particular focus lies in its contribution to the academic literature of the background context of teachers working in private schools where there is a lack of research on this area and where discussions around it are taken by the local media outlets solely. This review will be crucial for researchers who are interested in the process of preparing teachers in this context and for those who are interested in pursuing a career in teaching in the Saudi private sector.
\end{abstract}

\section{Introduction}

The formal educational system in Saudi Arabia was founded in 1925 by the establishment of the Directorate of Knowledge to supervise four primary schools [1]. Later, in 1951, the Ministry of Knowledge was established to plan and supervise general education [1, 2]. Since 2002, the Ministry of Education (MOE) has been responsible for all aspects of schooling, including two additional levels: pre-school and university [3]. The current general education system has thus been developed through many phases. It comprises three levels: primary/elementary (six years), intermediate (three years) and secondary/high school (three years) [3]. It is vital to highlight the variances of the three types of general education schools in Saudi Arabia: Public schools, private schools and international $[4,5]$. See Table 1. for further details of schools in each sector.

The Saudi Arabia Kingdom pays a great deal of attention to schools in the public sector by spending a large amount of money to construct and maintain buildings, provide teachers' salaries, equipment, educational supervisors, materials, curriculum textbooks and technology [6].
Table 1. Systems of teacher preparation programmes in Saudi Arabia

\begin{tabular}{|c|c|}
\hline $\begin{array}{c}\text { State/ public } \\
\text { schools }\end{array}$ & $\begin{array}{c}\text { Offered to all pupils without fees as } \\
\text { they are funded in whole by the } \\
\text { government for all general education } \\
\text { stages }\end{array}$ \\
$\begin{array}{c}\text { Private/ } \\
\text { independent } \\
\text { schools }\end{array}$ & $\begin{array}{c}\text { They are non-governmental and require } \\
\text { tuition fees to enrol in their } \\
\text { programmes of study }\end{array}$ \\
\hline $\begin{array}{c}\text { Internationa } \\
\text { l/ foreign } \\
\text { schools }\end{array}$ & $\begin{array}{c}\text { They are also non-governmental and } \\
\text { promote international education by } \\
\text { following a national curriculum } \\
\text { different from that of the state and } \\
\text { private schools' country of residence }\end{array}$ \\
\hline
\end{tabular}

For schools in the private sector, the MOE does not provide teachers' salaries, buildings or equipment to these schools. However, they provide educational supervisors, educational materials, curricula and textbooks, and they must follow the educational policies, guidelines and curricula of the MOE. Additionally, the 'teachers teaching in both private and public schools are more often than not graduates of the same teacher education program taught at the College of Education' [7]. One of the main educational policies, for the first two types (private and public schools), asserts that all levels in general education, except for nursery and pre-school, should be gender-segregated [8, Article 155]. This policy asserts that female pupils, teachers and staff have a separate setting from males, which leads to separate school buildings for each gender.

\section{Literature Review}

There is a great deal of previous research on teacher education and the teaching profession [e.g. 915]. These studies have discussed various issues that teachers face in their teaching profession. Many issues have been raised by these studies are significant such as issues of teachers' initial preparation and the encountered dilemmas when they practice teaching. These studies have looked at different knowledge bases teachers might lack when 
starting their career which includes: Content Knowledge (CK), General Pedagogical Knowledge (GPK) and Pedagogical Content Knowledge (PCK). Furthermore, these studies [13], [14] have shed the light on the issue of the predominance of theory over practice in their preparation which causes a challenge for teachers when they start teaching. However, little attention has been given towards the issues teachers face in regard to the sector they work in Saudi Arabia. This area of research is important to discuss teachers' issues as the ones who work in the private sector might face different dilemmas than those who work in the public sector which might influence their teaching experiences and performances. To the best of my knowledge, there is one study [16] in the Saudi context that discusses the challenging concerns of teachers in the private sector, and this study was focusing on pre-school teachers only. It is essential to provide an overview of teaching history in Saudi Arabia, which is provided in the following section, before discussing how teaching in different sectors is 'different'.

\section{The history of the teaching profession and teaching preparation in Saudi Arabia}

It is crucial to review the history of Saudi education and that general issues that faced it regarding teachers and the teaching career to provide an understanding of the fundamental changes that might have shaped the current status of Saudi teachers. Looking at the educational history of Saudi Arabia, the first problem the Directorate of Knowledge faced was preparing Saudi qualified teachers to open and prepare new schools [2]. The Directorate of Knowledge recruited teachers from neighbouring Arab countries for many years, which was a temporary solution before starting native teacher preparation programmes [2]. The Directorate of Knowledge envisioned the need for preparing native teachers as a way to create job opportunities for Saudi citizens and also to meet the increasing demand for schools and teachers over the country. These preparation programmes resulted half a million $(480,900)$ Saudi teachers [17]. Over eight decades, several shifts and reforms in teacher preparation have occurred in the Kingdom. As mentioned earlier, it appears that 90 years ago, there was a lack of Saudi cadres working in the teaching profession. To meet the increasing need for schools that started spreading in the country, the government needed to make a fast decision to prepare teachers. Hence, the Directorate of Knowledge established scientific institutes in 1926 for teacher preparation in many regions of the Kingdom [2], [9]. These institutes established educational and specialised programmes for two years. Students-teachers could join these institutes immediately after graduation from the intermediate school. This means that the Saudi teachers who teach primary schools were too young at that time - not yet eighteen years old. Then, these institutes were upgraded to become three-year secondary institutes, and at a later stage the institutes were abolished and transformed into intermediate colleges, and, finally, teachers' colleges were granted the ability to confer a bachelor's degree in education after four academic years [2]. These colleges expanded their programmes and specialisations, increased their enrolment and acceptance numbers of students from high school graduates and spread across the country. In 2005, the Saudi government had over 20 universities [10]. A few years later, teachers' colleges joined existing universities in each region, and thus moved away from the direct educational field to the general educational field [2]. Currently, graduates of any major (e.g. English, Arabic or mathematics) can work as teachers by completing an additional educational preparation for their bachelor's degree [9], [11], [17], [18]. This means that each university has its own teacher preparation programme. These programmes operate under two systems (see Table 2).

Table 2. Systems of teacher preparation programmes in Saudi Arabia

\begin{tabular}{|c|c|c|c|}
\hline & $\begin{array}{l}\text { Integrated } \\
\text { system }\end{array}$ & \multicolumn{2}{|c|}{$\begin{array}{c}\text { Sequential/ consecutive } \\
\text { system }\end{array}$} \\
\hline$\frac{0}{\frac{0}{z}}$ & $\begin{array}{c}\text { Specialisation } \\
\text { modules } \\
+ \\
\text { Educational } \\
\text { modules }\end{array}$ & $\begin{array}{l}\text { Specialisation } \\
\text { modules }\end{array}$ & $\begin{array}{l}\text { Educational } \\
\text { modules }\end{array}$ \\
\hline : & 5 years & 4 years & 1 year \\
\hline 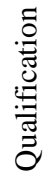 & $\begin{array}{l}\text { Bachelor's } \\
\text { degree with } \\
\text { educational } \\
\text { preparation }\end{array}$ & $\begin{array}{l}\text { Bachelor's } \\
\text { degree }\end{array}$ & $\begin{array}{l}\text { Educational } \\
\text { preparation } \\
\text { diploma }\end{array}$ \\
\hline
\end{tabular}

The integrated system requires undergraduate students to study their specialisation modules alongside the educational modules, whereas the sequential/ consecutive system requires undergraduate students to study their specialisation in their university department then join the educational preparation diploma programme at the College of Education [9], [11], [12], [18]. Currently, the sequential/consecutive system is the only one used in Saudi Arabia [11], which means studentteachers are not introduced to educational 
preparation or practical training until they finish their fourth year of studying their subject modules and receive a bachelor's degree. Therefore, teachers of any subject study modules, which are distributed into three domains: subject preparation, pedagogical preparation and cultural preparation [13], [14], [19]. The current teacher preparation programmes in the Kingdom are not specified for primary, intermediate or secondary teacher education [19], which means student-teachers who graduate from these programmes are qualified to teach any of the general education levels. There are some new changes planned for teacher preparation programmes, such as the acceptance criteria of student-teachers, the number of years of educational preparation and the use of both the integrated and the consecutive systems, depending on the major and level of the student [14]. However, all these changes have not yet been implemented.

\section{Teaching in private vs public sector}

The number of Saudi teachers today [17] suggests that teaching is a favourable career in Saudi Arabia. It is a well-paying job with other advantages; thus, it has become an in-demand occupation [20]. It is noteworthy that when talking about high salaries, this is mostly true of teachers who work only in public schools. Teaching in public schools in Saudi Arabia is "very attractive for recent graduates due to high salaries and benefits, job security, and social status' [16]. For better understanding, teachers who graduate from the same teacher preparation programmes can work for either private or public schools. They both share similar responsibilities, teach the same curriculum and get equal in-service training, administered by the same supervisors under the MOE umbrella. However, according to Al-Shatry [20], the duties of private schools' teachers are greater than the duties of public schools' teachers, and usually, they are overloaded by administrative tasks. Thus, many teachers leave the job shortly after being hired, which leaves those who remain, having to deal with a large number of students [16]. Income and job opportunities are not the same in both settings [20], [16]. Al-Shatry [20] states that, due to the lack of teaching jobs in state schools, many Saudi teachers choose to work on a temporary basis in private schools to gain teaching experience that helps them to obtain jobs in state schools. Gahwaji [16] adds that working in private schools means no paid emergency and sick leaves as in state schools. These statements are supported by my own experience as a private school teacher. It is quite easy to get a teaching job in the private sector immediately after graduation, but the salary is extremely low compared to salaries at public school, besides, teacher feels overloaded and lacks job stability in the private sector. Unfortunately, it normally takes many years to get a teaching job in a public school, even if a teacher is highly qualified. This results in private school beginner teachers mostly lacking a priori teaching experience, whereas beginner teachers in public schools are usually not really beginners, as they have some experience working in private schools while waiting for the 'dream job' [20]

\section{Discussion}

This paper has detailed the issues of teachers who work in the private sector. The reason why this is an important issue to discuss is that there is a lack of academic literature in this regard. It seems from the above overview that teachers in the private sector might have different experiences in comparison to teachers in the public sector. Differences between jobs features are unfair, especially when they require the same preparation and qualification. This would have an influence on teacher's performance or, as Gahwaji [16] points out, lead to teachers' turnover from the teaching profession.

\section{Recommendations}

This paper recommends further investigation and comparative research in teachers experiences within the two sectors. It is essential to understand how teachers perceive their occupation when working in private and public schools in the Saudi context. This would provide a detailed picture of the issues underpinning teachers' experiences in both sectors and would give an enhanced understanding of how teachers view themselves, their work, and their profession.

\section{Conclusion}

In summary, it can be concluded that the MOE pays great attention to teachers' education in Saudi Arabia. However, there are many challenges that face teachers when starting their profession, especially when they are employed in the private sector. The MOE in Saudi Arabia needs to review the situation of private school teachers and adopt solutions to achieve equality between teachers in public and private schools in terms of teachers' responsibilities, salaries and their job stability.

\section{References}

[1] Ministry of Education (MOE), (2020). Establishment of the Ministry of Education. https://www.moe.gov.sa (Access Date: April 27, 2020).

[2] Hakeem A., (2012). Education system and policy [Translated from Arabic]. Cairo: Etrac publishing. 
[3] Ministry of Education (MOE), (2020). Objectives 2020 https://www.moe.gov.sa/ar/PublicEducation/ResidentsAnd Visitors/Pages/TooAndAimsOfEducation.aspx (Access D ate: April 27, 2020).

[4] Ministry of Education (MOE), (2020). General Public Education; https://www.moe.gov.sa/AR/P UBLICEDUCA TION/GOV/Pages/default.aspx (Access Date: April 27, 2020).

[5] Ministry of Education (MOE), (2020). General Private Education, https://www.moe.gov.sa/AR/PUBLICEDUCA TION/PRIVATEFORIEGN/Pages/default.aspx (Access D ate: April 27, 2020).

[6] Al-Blaihed M. A., (2016). Saudi Arabian Science and Mathematics Pre-service Teachers' Perceptions and Practices of the Integration of Technology in the Classroom [dissertation on the Internet]. University of Exeter. https://ore.exeter.ac.uk/repository/handle/10871/24 046 (Access Date: April 27, 2020).

[7] Jamjoom M. I., (2010). Female Islamic Studies teachers in Saudi Arabia: A phenomenological study. Teaching and Teacher Education, 26(3):547-58.

[8] Ministry of Education (MOE), (1970). The document of Educational Policy in the Kingdom of Saudi Arabia [Translated from Arabic]. Riyadh: Ministry of Education.

[9] Al-Ghamdi A, Li L., (2012). Teaching Arabic and the Preparation of its Teachers before Service in the Kingdom of Saudi Arabia. International Journal for CrossDisciplinary Subjects in Education (IJCDSE), (1):661-4.

[10] Al-Manea M, A., (2010), Teacher preparation programs between rigidity and development [Translated from Arabic]. In: Education Development: visions, models, requirements. Proceedings of the 5th annual meeting of Saudi society of educational and phycological science. Jan 5-6; Imam Muhammad bin Saud Islamic University, Saudi Arabia, Riyadh: College of Education, p. 593-602. http://search.shamaa.org/PDF/43858/15GESTEN 43880Y2010.pdf (Access Date: April 27, 2020).

[11] Al-Zaydi D. A., (2010). Activity theory as a lens to explore participant perspective of the administrative and academic activity systems in a university-school partnership in initial education in Saudi Arabia [dissertation on the Internet]. Exeter, United Kingdom: University of Exeter. https://ore.exeter.ac.uk/repository/ha ndle/10036/120097 (Access Date: April 27, 2020).

[12] Binjumah S. M., (2017). Using Activity Theory to Explore the Perspectives of Participants on an Initial Teacher Education Programme for Science Teachers in the Kingdom of Saudi Arabia [dissertation on the Internet]. University of Exeter. https://ore.exeter.ac.uk/repository/ha ndle/10871/31032 (Access Date: April 27, 2020).

[13] Al-Aqili A., (2011). Teaching strategies and evaluation methods used in Arabic language teacher preparation program in teacher colleges in the Kingdom of Saudi Arabia: an analytical study [Translated from Arabic]. Educational Journal, 1(146):99-146.
[14] Ministry of Education (MOE), (2020). The general framework for developing teacher preparation programs in Saudi universities [Translated from Arabic]. Riyadh: The planing and develpment agency in MOE.

[15] Al-Jadidi N. A., (2012). The professional preparation, knowledge and beliefs of kindergarten teachers in Saudi Arabia [dissertation on the Internet]. University of Exeter. https://ore.exeter.ac.uk/repository/handle/10036/3892 (Ac cess Date: April 27, 2020).

[16] Gahwaji N., (2013). Controversial and challenging concerns regarding status of Saudi preschool teachers. Contemporary Issues in Education Research (CIER), 6(3):333-44.

[17] Ministry of Education (MOE), (2019). General Education data. https://departments.moe.gov.sa/PlanningD evelopment/RelatedDepartments/Educationstatisticscenter/ OpenData/OpenData1440/bar1440_1439.html (Access Da te: April 27, 2020).

[18] Abdulatheem S., Abdulfattah R., (2017). Teacher Preparation in the Light of the Experiences of Some Countries [Translated from Arabic]. Cairo: Arab Group.

[19] Al-Saud A. F., (2006). Evaluating the reality and performance of females' colleges of education in Saudi Arabia in preparing Arabic language teacher for various education levels - a field study [Translated from Arabic]. Proceedings of the 7th International Scientific Conference. April, Al Fayoum: Egypt, p. 127-190.

[20] Al-Shatry K., (2011). An internal view: To support the Saudi teacher in private schools [Translated from Arabic]. Al-Riyadh newspaper, July. 